POÓR József - KISS Katalin - GROSS András FRANCSOVICS Anna

\title{
KIS- ÉS KÖZÉPVÁLLALKOZÁSOK FEJLŐDÉSÉNEK VIZSGÁLATA EGY EMPIRIKUS FELMÉRÉS TÜKRÉBEN
}

A kis- és közepes vállalkozások (KKV) egyre jelentốsebb szerepet töltenek be a magyar gazdaság életében. A belsố és külsố problémáik ellenére is képességet mutatnak a túlélésre. Az elmúlt évtized során ezek a vállalkozások kezdik figyelmüket az ország határain túli piaci lehetôségekre irányítani. A vállalkozások indításához és múkködtetéséhez szükséges vállalkozási, menedzseri és szakmai képességeik kezdenek elkülönülni. A cégeket alapító tulajdonosok teret engednek külsố menedzsereknek, és szakembereket alkalmaznak speciális feladatok megoldására. Az empirikus kutatásban 112 magyar kis- és közepes vállalkozás vett részt, amelyekról elmondható, hogy kisebb-nagyobb erófeszítések árán, de sikereket értek el az 1987-tól 2005-ig terjedó idôszakban.

Kulcsszavak: kis- és közepes vállalkozások (KKV), gazdasági teljesítmény, Magyarország

E tanulmány megírásakor közvetlen kutatási eredményekre' támaszkodtunk. Az empirikus kutatás egy alapos és részletes felmérés volt 112 olyan magyar cég részvételével, amelyek megfelelnek a KKV-k kritériumainak. A vállalkozások csoportosítása a mérhetô és statisztikailag nyilvántartott értékek alapján történt, az elhatárolás az EU előírása szerint egységesen a következő: kis- és középvállalkozás (KKV) az a vállalkozás, amelyre vonatkozóan a következő feltételek állnak fenn:

- összes foglalkoztatotti létszáma 250 fónél kevesebb és

- éves nettó árbevétele legfeljebb ötvenmillió eurónak megfelelő forint vagy mérlegfóösszege legfeljebb 43 millió eurónak megfelelő forintösszeg.

A KKV-kategórián belül kisvállalkozásnak minősül az a vállalkozás, amelynek

- összes foglalkoztatotti létszáma 50 főnél kevesebb,

- éves nettó árbevétele vagy mérlegfőösszege legfeljebb tízmillió eurónak megfelelő forintösszeg.

A KKV-kategórián belül mikrovállalkozásnak minôsül az a vállalkozás, amelynek

- összes foglalkoztatotti létszáma 10 fônél kevesebb és

- éves nettó árbevétele vagy mérlegfőösszege legfeljebb 2 millió eurónak megfeleló forintösszeg.
További feltétel, hogy egy vállalkozás akkor minôsül kis- és középvállalkozásnak, ha abban az állam, az önkormányzat vagy valamely nagyvállalkozás tulajdoni részesedése - tőke vagy szavazati jog alapján - külön-külön és együttesen sem haladja meg a $25 \%$-ot.

A kisvállalkozásokról tett megállapításokat értelemszerúen kiterjesztve használjuk a mikrovállalkozásokra is, és jellemző vonásaikat elsődlegesen a hazai viszonyok alapján vizsgáljuk.

A hangsúly a különböző vállalatirányítási gyakorlatokon volt a cégek életciklusának különböző fázisaiban.

A 2006-os, magyarországi KKV-k körében végzett felmérésben 112 vállalkozás vett részt. A véletlenszerú mintát a Magyar Kereskedelmi Kamara, illetve a Kisés Középvállalkozások Szövetségének adatbázisából vettük. A 112 vállalkozás Magyarország minden régióját lefedi. A fővárosi és Pest megyei vállalkozások az összes elemzett vállalkozások egyötödét teszik ki. Ugyancsak eltérő iparágakat reprezentálnak a résztvevốk. $22 \%$ a termelés, $13 \%$ az építóipar, $20 \%$ a kereskedelem, a többi pedig fốként a különbözô szolgáltató ágazatokat képviseli. Körülbelül kétharmaduk korlátolt felelôsségú társaságként (kft.) múködik. 
Kutatásunk keresztmetszeti, nem időben kiterjedő, ugyanak-

A vizsgált KKV-k megalapításának éve $(\mathrm{n}=112)$ kor a 112 vállalkozás kialakulásának és további életciklusainak vizsgálatára vonatkozóan számos többirányú kérdést is feltettünk. Ezek a következók voltak: írja le (1) a szervezet megalakulásának, megalapításának időszakát, (2) az intenzív növekedés, megerősödés idejét és (3) közvetlenül az Európai Unióhoz való csatlakozásunk (2004) utáni helyzetét. A múlt évszázad 70-es évei óta számos szerző (Greiner, 1972; Kazanjian, 1988; Kazanjian - Drazin, 1989;

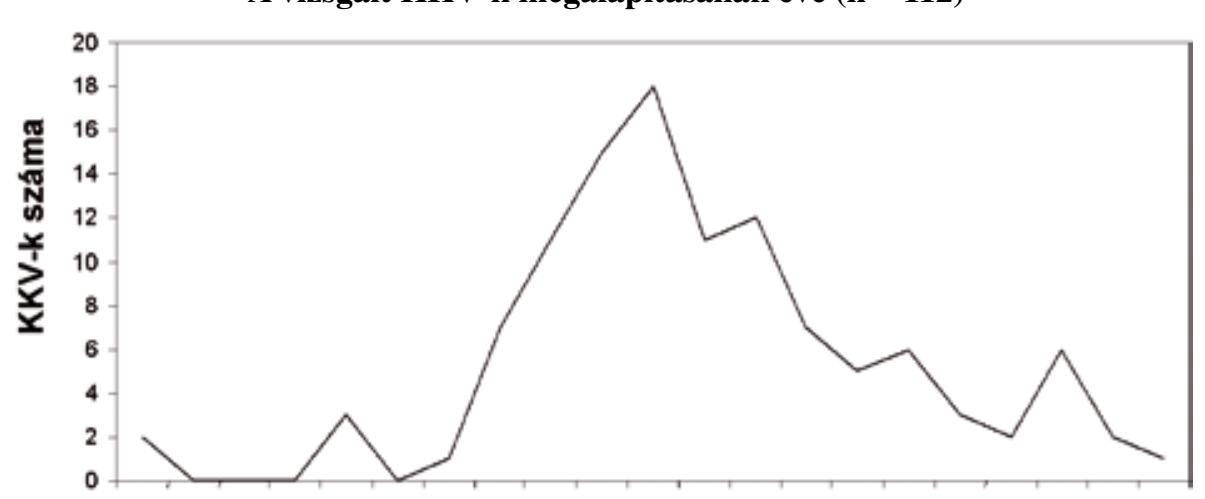

198219831984198519861987198819891990199119921993199419951996199719981999200020012002

Alapítás éve

A 2. ábra az intenzív növekedés, a megerôsödés éveit szemlélteti, amely folyamatok természetszerúleg az 1990-es évek második felét jellemezték. Ezt az időszakot aztán a meredek visszaesés követi, miközben a verseny is fokozottabbá vált.

2. ábra

A vizsgált KKV-k megerősödésének időszaka $(\mathrm{n}=112)$

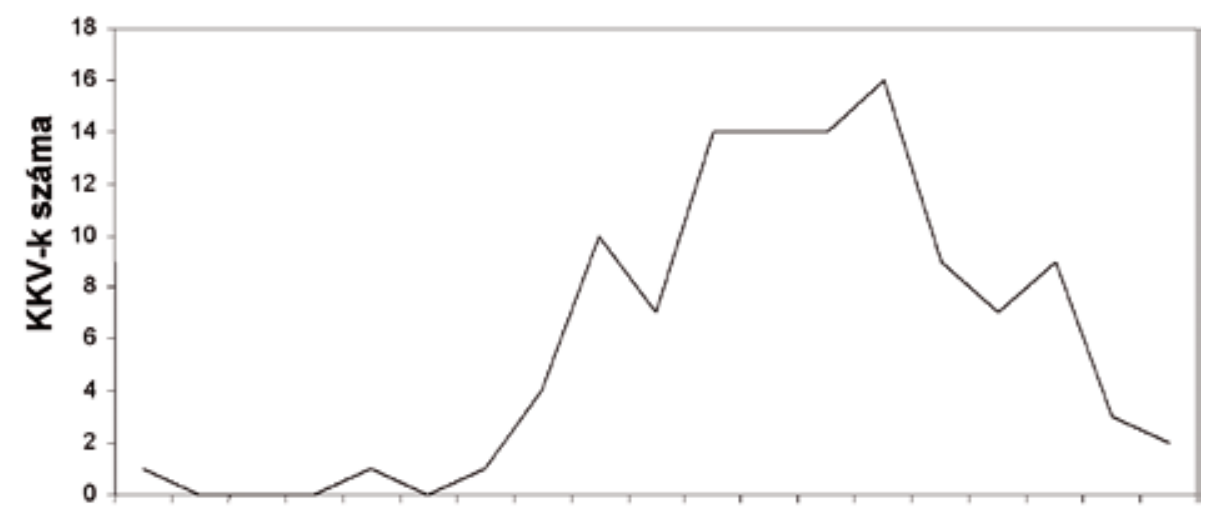

1987198819891990199119921993199419951996199719981999200020012002200320042005
Mely kulcsfontosságú tényezók játszottak szerepet a vállalkozások megalapításában? A válaszadók kétharmada nyilatkozott úgy, hogy saját elhatározásuk, azaz önkéntes volt a cégalapítás. Csupán $8 \%$ említette a privatizációt, $6 \%$ a ,szükségszerúséget” vagy „kényszerítő körülményeket", $11 \%$ az átszervezést és $7 \%$ egyéb okokat jelölt meg. Az 1. táblázat részletezi az összes foglalkoztatott megoszlását az említett három időszakban.

\section{Megerósø̋dés évei}

növekedés különböző fázisaira, a befolyásoló tényezók függvényében, meghatározzák a lényeges következmén yeket"(Rutherford et al., 2003: 321. o.). Nincs egyértelmú bizonyíték arra vonatkozóan, hogy hány fázissal lehet leírni egy-egy szervezet életciklusát, az értékek 3 és 10 között mozognak.

A válaszok bepillantást nyújtanak abba a folyamatba, ahogyan ezek a mikro-, kis- és középvállalkozások reagáltak a változásokra. Az 1. ábrán grafikusan ábrázoljuk a vállalkozások megalapításának évét. A kapott válaszok alapján, amint az várható volt, az 1990-es évek első fele bizonyult a cégalapítások legnépszerúbb időszakának. Azt követôen meredek zuhanás mutatkozik, hisz a kezdeti optimizmust a realitások visszavetették.
Összes foglalkoztatott megoszlása a vállalkozások mérete szerint ( $\mathrm{n}=112$ vállalkozás)

\begin{tabular}{|l|c|c|c|c|}
\hline $\begin{array}{c}\text { Vállalat } \\
\text { típusa }\end{array}$ & $\begin{array}{c}\text { Vállalat } \\
\text { mérete } \\
\text { (Foglal- } \\
\text { koztatot- } \\
\text { tak száma } \\
\text { szerint) }\end{array}$ & $\begin{array}{c}\text { Meg- } \\
\text { alakuláskor } \\
\mathbf{1 9 9 2 +}\end{array}$ & $\begin{array}{c}\text { Megeró- } \\
\text { södéskor } \\
\mathbf{1 9 9 8 +}\end{array}$ & $\begin{array}{c}\text { EU-csat- } \\
\text { lakozás } \\
\text { után } \\
\mathbf{2 0 0 4 +}\end{array}$ \\
\hline Mikro & $1-9$ & $69 \%$ & $34 \%$ & $29 \%$ \\
\hline Kicsi & $11-49$ & $18 \%$ & $44 \%$ & $43 \%$ \\
\hline Közepes & $50-249$ & $13 \%$ & $22 \%$ & $28 \%$ \\
\hline Összesen & & $\mathbf{1 0 0 , 0 \%}$ & $\mathbf{1 0 0 , 0 \%}$ & $\mathbf{1 0 0 , 0 \%}$ \\
\hline
\end{tabular}


A megalakulás idején, túlnyomó részben 1992 körül, a vállalatok közel 70\%-a tartozott a mikrovállalkozások kategóriájába. Az EU-csatlakozás idejére ez a kategória az összesnek kevesebb mint 30\%-át tette ki. A cégek „felnövekedtek”. Az 1992-2004 közötti időszakban a tényleges foglalkoztatás tekintetében növekedést látunk a 2. táblázat adatai szerint. A vonalbeli vezetók és az egyéb alkalmazottak száma évenkénti 5\%-os emelkedést mutat. A közvetlen vezetôi szint nem duzzadt föl és nem vált bürokratikussá. A menedzsment aránya évenkénti 3,3\%-os ütemben nôtt.

2. táblázat

A dolgozók csoportjainak megoszlása

( $\mathrm{n}=112$ vállalkozás)

\begin{tabular}{|l|c|c|c|}
\hline Dolgozói csoportok & $\begin{array}{c}\text { Megalaku- } \\
\text { láskor } \\
\mathbf{1 9 9 2 +}\end{array}$ & $\begin{array}{c}\text { Megeró- } \\
\text { södéskor } \\
\mathbf{1 9 9 8 +}\end{array}$ & $\begin{array}{c}\text { EU-csatla- } \\
\text { kozás után } \\
\text { 2004+ }\end{array}$ \\
\hline $\begin{array}{l}\text { Vonalbeli vezetók és } \\
\text { az egyéb alkalmazottak }\end{array}$ & 2379 & 3624 & 4274 \\
\hline Vezetók & 307 & 400 & 455 \\
\hline Összesen & $\mathbf{2 6 8 7}$ & $\mathbf{4 0 2 3}$ & $\mathbf{4 7 2 9}$ \\
\hline
\end{tabular}

Míg a dolgozók létszámának növekedése bármely méretû vállalat esetében az egészséges növekedés jele, az értékesítés növekedése mégis fontosabbnak túnik. A 3. táblázat adatai ezt az erôsen növekvő trendet illusztrálják a hármas megosztás szerint. Jóllehet, a vállalkozások több mint 60\%-ának nagyon szerény mértékú volt a forgalma az 1990-es évek elején (20 millió forint alatt, vagyis kevesebb mint 70 ezer dollár az akkori árfolyamon), 2004-re csupán 8\%-uk tartozott ebbe a kategóriába, a többi cég markáns növekedést jelez. Valójában 2004-re a vizsgált cégek több mint egyötödének a forgalma meghaladta az egymilliárd forintot, azaz a 40 millió dollárt.

3. táblázat

A felmérésben részt vevő KKV-szektor éves forgalma ( $\mathrm{n}=112$ vállalkozás)

\begin{tabular}{|c|c|c|c|}
\hline $\begin{array}{c}\text { Éves forgalom/ér- } \\
\text { tékesítés (millió } \\
\text { forintban*) }\end{array}$ & $\begin{array}{c}\text { Meg- } \\
\text { alakuláskor } \\
\mathbf{1 9 9 2 +}\end{array}$ & $\begin{array}{c}\text { Megeró- } \\
\text { södéskor } \\
\mathbf{1 9 9 8 +}\end{array}$ & $\begin{array}{c}\text { EU-csatla- } \\
\text { kozás után } \\
\mathbf{2 0 0 4 +}\end{array}$ \\
\hline 20 alatt & $63 \%$ & $5 \%$ & $8 \%$ \\
\hline $20-49$ & $14 \%$ & $20 \%$ & $12 \%$ \\
\hline $50-99$ & $8 \%$ & $18 \%$ & $14 \%$ \\
\hline $100-499$ & $8 \%$ & $35 \%$ & $32 \%$ \\
\hline $500-999$ & $5 \%$ & $11 \%$ & $12 \%$ \\
\hline $1000+$ & $1 \%$ & $12 \%$ & $22 \%$ \\
\hline Összesen & $\mathbf{1 0 0 \%}$ & $\mathbf{1 0 0 \%}$ & $\mathbf{1 0 0 \%}$ \\
\hline
\end{tabular}

Megjegyzés: * 1 USD = 200 forint 2005-ben (ettôl eltérő a megelőzó években, pl. 1 USD = 300 forint 2000-ben)
Az eddigi elemzések a statisztikák mellett bepillantást nyújtanak az elmúlt két évtized trendjeibe. Általános szabályként elmondható, hogy a KKV-k múködésük és teljesítményük tekintetében a változó belsô és külső körülményeket állandóan figyelemmel kísérik, és szükség esetén azonnali változtatásokat hajtanak végre. A 4. táblázat szerint a vállalkozások fennállásuk óta számos kihívással néztek szembe. Bár a változásokat elôidézô folyamatok közül egyik sem került jelentős túlsúlyba a másikkal szemben, a teljesítményjavítás "többféle" lehetôségével (pl. az átszervezés, termelésfejlesztés, szervezetfejlesztés stb. kombinációjával) a vállalatok háromnegyede élt mind a megerősödés évében, mind az EU-csatlakozás időszakában.

Csupán azoknak a vállalkozásoknak az aránya volt és maradt jelentős - 13-14\% -, amelyek bóvítették termék-, illetve szolgáltatási területeiket. A vállalkozások egy része nem változtatott a tevékenységi körén sem a megerôsödés, sem az EU-csatlakozás utáni időszakban. Újabb tevékenységi köröket csak kis részük hozott létre.

4. táblázat

Tipikus változást kiváltó okok ( $\mathrm{n}=112$ vállalkozás)

\begin{tabular}{|l|c|c|}
\hline \multicolumn{1}{|c|}{ Változások } & $\begin{array}{c}\text { Megeró- } \\
\text { södéskor } \\
\mathbf{1 9 9 8 +}\end{array}$ & $\begin{array}{c}\text { EU-csatla- } \\
\text { kozás után } \\
\mathbf{2 0 0 4 +}\end{array}$ \\
\hline Szervezetfejlesztés & $6 \%$ & $5 \%$ \\
\hline Átszervezés & $10 \%$ & $2 \%$ \\
\hline Termék-/szolgáltatás bővítés & $13 \%$ & $14 \%$ \\
\hline Termelésfejlesztés & $7 \%$ & $4 \%$ \\
\hline Környezetvédelmi beruházás & $2 \%$ & $0 \%$ \\
\hline Egyéb & $9 \%$ & $2 \%$ \\
\hline Többféle & $44 \%$ & $73 \%$ \\
\hline Nem & $10 \%$ & $0 \%$ \\
\hline Összesen & $\mathbf{1 0 0 \%}$ & $\mathbf{1 0 0 \%}$ \\
\hline
\end{tabular}

Igénybe vettek-e a vállalkozások pénzügyi és emberierôforrás-támogatást, segítséget? Arra a kérdésre, hogy csak saját tókét használtak-e föl a vállalkozás beindításához, múködtetéséhez, 58\%-uk adott igenlő választ, ez azonban csak a cégalapítás időszakára vonatkozott. A megerôsödés éveiben ez az arány 35\%-ra csökkent, 2000-re pedig 30\%-ra. A kockázatitóke-befektetók és banki hitelek bevonása minimális szerepet játszott, ezzel szemben a többféle lehetőség kombinációja vált jellemzően népszerúvé, az alakulás évében jelzett 26\%-ról 2004-re 54\%-ra emelkedett. Az 5. táblázat adatai alapján a KKV-k többsége a megerôsödés időszakában pályázati pénz- 
eszközöket és hasonló támogatásokat vett igénybe, míg a vállalkozások egynegyede-egyharmada továbbra sem élt ezzel a lehetőséggel.

A vállalkozások irányításáról a 6. táblázat alapján elmondható, hogy a tisztán tulajdonosokból álló menedzsment aránya az alapítás időszakában jellemző 80\%-ról 12 év alatt, azaz 2004-re 63\%-ra csökkent.

5. táblázat

Támogatások igénybevétele ( $\mathrm{n}=112$ vállalkozás)

\begin{tabular}{|l|c|c|}
\hline \multicolumn{1}{|c|}{ Támogatások típusa } & $\begin{array}{c}\text { Megeró- } \\
\text { södéskor } \\
\mathbf{1 9 9 8 +}\end{array}$ & $\begin{array}{c}\text { EU-csatla- } \\
\text { kozás után } \\
\mathbf{2 0 0 4 +}\end{array}$ \\
\hline Magyar pályázat & $19 \%$ & $13 \%$ \\
\hline EU-pályázat & $2 \%$ & $4 \%$ \\
\hline Állami támogatás & $4 \%$ & $1 \%$ \\
\hline Hiteltámogatás & $18 \%$ & $12 \%$ \\
\hline Egyéb támogatás & $5 \%$ & $3 \%$ \\
\hline Többféle & $29 \%$ & $34 \%$ \\
\hline Semmilyen & $24 \%$ & $33 \%$ \\
\hline Összesen & $\mathbf{1 0 0 \%}$ & $\mathbf{1 0 0 \%}$ \\
\hline
\end{tabular}

A vállalkozások

operatív irányítása a vizsgált három időszakban ( $\mathrm{n}=112$ vállalkozás)

\begin{tabular}{|l|c|c|c|}
\hline \multicolumn{1}{|c|}{$\begin{array}{c}\text { A vállalkozás operatív } \\
\text { irányítása }\end{array}$} & $\begin{array}{c}\text { Meg-ala- } \\
\text { kuláskor } \\
\mathbf{1 9 9 2 +}\end{array}$ & $\begin{array}{c}\text { Megeró- } \\
\text { södéskor } \\
\mathbf{1 9 9 8 +}\end{array}$ & $\begin{array}{c}\text { EU-csat- } \\
\text { lakozás } \\
\text { után } \\
\mathbf{2 0 0 4 +}\end{array}$ \\
\hline $\begin{array}{l}\text { Tulajdonosokból álló } \\
\text { menedzsment }\end{array}$ & $80 \%$ & $73 \%$ & $63 \%$ \\
\hline $\begin{array}{l}\text { Nem tulajdonosokból álló } \\
\text { menedzsment }\end{array}$ & $15 \%$ & $13 \%$ & $16 \%$ \\
\hline Vegyes & $4 \%$ & $14 \%$ & $21 \%$ \\
\hline
\end{tabular}

Mely területekre irányult a KKV-k tevékenysége? A 7. táblázat adatai szerint az évek során többirányúvá és változatossá vált, a termék-előállítástól az általános szolgáltatásokig terjedően.

A piaci lehetőségek felkutatásában a 8 . táblázat alapján elmondható, hogy jelentős változás tapasztalható. Míg az 1990-es évek elején még 78\%-ban a hazai piacokat célozták meg a vizsgált KKV-k, 2004re ez az arány már csupán 48\%-ot ért el. Más megközelítésben elmondható, hogy a külföldi piacok fontossága - nem csak Európában - jelentősen megnőtt, és 2004-ben a több helyszínen zajló tevékenység, jelenlét a KKV-k közel 50\%-ának múködésére jellemző volt. Ez a jelenség igazán figyelemre méltó, és jelzi a gyakran emlegetett vállalkozói és nemzetközi orientáltságot még a „zavaros” idókben, az élesedő versenyhelyzetben is.

7. táblázat

A vállalkozások tevékenységi területei (n = 112 vállalkozás)

\begin{tabular}{|l|c|c|c|}
\hline Tevékenységi területek & $\begin{array}{c}\text { Megala- } \\
\text { kuláskor } \\
\mathbf{1 9 9 2 +}\end{array}$ & $\begin{array}{c}\text { Megeró- } \\
\text { södéskor } \\
\mathbf{1 9 9 8 +}\end{array}$ & $\begin{array}{c}\text { EU-csatla- } \\
\text { kozás után } \\
\mathbf{2 0 0 4 +}\end{array}$ \\
\hline Termékek & $21 \%$ & $15 \%$ & $14 \%$ \\
\hline $\begin{array}{l}\text { Általános } \\
\text { szolgáltatások }\end{array}$ & $38 \%$ & $34 \%$ & $28 \%$ \\
\hline Kutatás-fejlesztés & $4 \%$ & $3 \%$ & $4 \%$ \\
\hline $\begin{array}{l}\text { Szakmai, szakértôi } \\
\text { szolgáltatások }\end{array}$ & $3 \%$ & $7 \%$ & $4 \%$ \\
\hline Egyéb & $9 \%$ & $7 \%$ & $13 \%$ \\
\hline Fentiek kombinációja & $24 \%$ & $34 \%$ & $37 \%$ \\
\hline Nincs változás & $0 \%$ & $0 \%$ & $1 \%$ \\
\hline Összesen & $\mathbf{1 0 0 \%}$ & $\mathbf{1 0 0 \%}$ & $\mathbf{1 0 0 \%}$ \\
\hline
\end{tabular}

8. táblázat

Piaci lehetôségek földrajzi megoszlása ( $\mathrm{n}=112$ vállalkozás)

\begin{tabular}{|l|c|c|c|}
\hline Földrajzi megoszlás & $\begin{array}{c}\text { Meg-ala- } \\
\text { kuláskor } \\
\mathbf{1 9 9 2 +}\end{array}$ & $\begin{array}{c}\text { Megeró- } \\
\text { södéskor } \\
\mathbf{1 9 9 8 +}\end{array}$ & $\begin{array}{c}\text { EU-csatla- } \\
\text { kozás után } \\
\mathbf{2 0 0 4 +}\end{array}$ \\
\hline Hazai piac & $78 \%$ & $57 \%$ & $48 \%$ \\
\hline Európa (EU) & $4 \%$ & $6 \%$ & $4 \%$ \\
\hline $\begin{array}{l}\text { Európa + 1 másik } \\
\text { kontinens }\end{array}$ & $1 \%$ & $0 \%$ & $1 \%$ \\
\hline Több helyszín & $17 \%$ & $37 \%$ & $47 \%$ \\
\hline Összesen & $\mathbf{1 0 0 \%}$ & $\mathbf{1 0 0 \%}$ & $\mathbf{1 0 0 \%}$ \\
\hline
\end{tabular}

A közelmúltban megváltoztak a főbb kihívást jelentő területek is. A 9. táblázat adatai szerint a kereslethiány miatt érzett vállalkozói aggodalom jelentősen fokozódott, hisz az 1990-es évek végére tapasztalható 13\%-kal szemben a válaszadók 23\%-a jelezte ugyanezt a tényezőt/jelenséget 2004-re és az utána következô időszakra jellemzônek. Ugyanakkor a tókehiány már kevésbé jelent gondot a válaszadók szerint, hisz a 90-es évek végén még 30\%-uknak, addig az EU-csatlakozás után 14\%-uknak kellett megküzdeniük ezzel a problémával. A ,több tényező kombinációja” okozta a legnagyobb kihívást a válaszadók közel 50\%-ának körében 2004-ben.

A jelenlegi bővítési tevékenységekrôl és elképzelésekról alkotott kép a 10. táblázat adataival szemléltet- 
hető. A KKV-k közel egyötöde válaszolta azt, hogy a kilencvenes évek végén és 2004-ben is azonos termékvonalon vagy szolgáltatási területen tevékenykedett. A termékskála-bôvítést, illetve az új tevékenységet választók aránya egyaránt csökkent ezen idôszak alatt. Mint korábban is, a komplexitás és a bizonytalanság kifejeződéseként a „több tényezô kombinációja” változatlanul domináns kategória maradt a válaszok közel felénél.

9. táblázat

\section{Fóbb kihívások} ( $\mathrm{n}=112$ vállalkozás $)$

\begin{tabular}{|l|c|c|}
\hline Fóbb kihívások/aggodalmak & $\begin{array}{c}\text { Megeró- } \\
\text { södéskor } \\
\mathbf{1 9 9 8 +}\end{array}$ & $\begin{array}{c}\text { EU-csatla- } \\
\text { kozás után } \\
\mathbf{2 0 0 4 +}\end{array}$ \\
\hline Kereslethiány & $13 \%$ & $23 \%$ \\
\hline Tókehiány & $30 \%$ & $14 \%$ \\
\hline Kapacitáshiány & $4 \%$ & $3 \%$ \\
\hline Emberi eróforrások hiánya & $4 \%$ & $4 \%$ \\
\hline Egyéb & $7 \%$ & $9 \%$ \\
\hline Fentiek kombinációja & $42 \%$ & $46 \%$ \\
\hline Nincsenek kihívások & $0 \%$ & $2 \%$ \\
\hline Összesen & $\mathbf{1 0 0 \%}$ & $\mathbf{1 0 0 \%}$ \\
\hline
\end{tabular}

10. táblázat

\section{Bóvítési tervek ( $\mathrm{n}=112$ vállalkozás $)$}

\begin{tabular}{|l|c|c|}
\hline \multicolumn{1}{|c|}{ Bôvítési tervek } & $\begin{array}{c}\text { Megeró- } \\
\text { södéskor } \\
\mathbf{1 9 9 8 +}\end{array}$ & $\begin{array}{c}\text { EU-csatla- } \\
\text { kozás után } \\
\mathbf{2 0 0 4 +}\end{array}$ \\
\hline $\begin{array}{l}\text { Azonos termékvonalon vagy } \\
\text { szolgáltatási területen }\end{array}$ & $18 \%$ & $20 \%$ \\
\hline $\begin{array}{l}\text { A termékvonal vagy szolgálta- } \\
\text { tási terület bóvítése }\end{array}$ & $31 \%$ & $29 \%$ \\
\hline Új tevékenység & $10 \%$ & $5 \%$ \\
\hline Új tulajdonos(ok) bevonása & $1 \%$ & $0 \%$ \\
\hline Egyéb & $1 \%$ & $0 \%$ \\
\hline Összetett, fentiek kombinációja & $39 \%$ & $46 \%$ \\
\hline Összesen & $\mathbf{1 0 0 \%}$ & $\mathbf{1 0 0 \%}$ \\
\hline
\end{tabular}

Az alapítás időszakában, ahogy korábban már írtuk, a legtöbb vállalat (63\%) nem ért el húszmillió forintnál nagyobb összegú árbevételt, azonban megfigyelhető, hogy ezek közül a legtöbb vállalkozás saját elhatározásból jött létre. Közülük 14\% 20 és 50 millió forint közötti árbevételt ért el, $8 \%$ pedig 50 és 100 millió forint közötti árbevételre tett szert. Ebból arra következtethetünk, hogy ezek a vállalkozások sikeresebbek azoknál, amelyek egyéb okból jöttek létre: a kényszervállalkozá- sok - összesen a vállalatok 5\%-a - szinte kivétel nélkül 20 millió forint alatti eredményt értek el. Mindemellett a Phi asszociációs mérőszám $(0,731)$ erős összefüggést feltételez az árbevétel alakulása és az alapítás oka között, ami magyarázza a kapott eredményt.

A különbözố cégek választott stratégiája is fontos tényezóként jelenik meg. A Phi asszociációs együttható $(0,564)$ alapján közepesen erôs az összefüggés a megerôsödés szakaszában kialakított stratégia és az árbevétel alakulása között.

Nagyobb árbevétel azokra a vállalatokra volt jellemző, amelyek stratégiája a megerósödés szakaszában a szolgáltatás létrehozása volt, illetve azoké, akik többféle stratégiát is kialakítottak. Akik a szolgáltatás kialakítására összpontosítottak, azok 36,8\%-ban értek el 50 és 100 millió forint közötti árbevételt, $16 \%$ pedig egymilliárd forint fölöttit. 37\% produkált 20 és 100 millió forint fölötti árbevételt. A cégek 34\%-a alkalmazott többféle stratégiát, ezek közül $42 \% 100$ és 500 millió forint közötti árbevételt termelt, míg a másik $42 \% 20$ és 100 millió forint közé eső árbevételt mutatott.

Összefüggés mutatkozik a menedzsment összetételében is. Az operatív irányítás és az árbevétel tekintetében a Phi együttható közepesen erôs összefüggést jelez. Kezdetben a vállalatok többségénél (80\%-uknál) a menedzsment jellemzóen a tulajdonosokból állt, csak $15 \%$-uknál volt a vezetôség külsô alkalmazott, és csak 5\%-ukban állt vegyesen tulajdonosokból és külső emberekből. Azok a vállalatok, amelyeknél a menedzsment a tulajdonosokból tevődött össze, 72\%-ban értek el húszmillió forint alatti bevételt az alapítás időszakában, 14\%-ban 20 és 50 millió forint között, valamint 13\%ban 100 millió és 1 milliárd között. Az EU-csatlakozás időszakában jobban megoszlanak ezek az adatok, de még mindig az jellemzô, hogy a vezetôség tulajdonosokból áll (a vállalatok 63\%-át vezetik a tulajdonosok, $16 \%$-át nem tulajdonosok és $21 \%$-át vegyesen). Ezek a tulajdonosok vezette vállalatok értek el nagyobb arányban magasabb árbevételt, 17\%-uk (az összes vállalat $11 \%$-a) tett szert egymilliárd fölötti bevételre. Az EUcsatlakozás időszakára vonatkozó Phi asszociációs mérôszám már csak gyenge összefüggést mutat az operatív irányítás és az árbevétel között. Ez alapján elmondható, hogy az alapítás idószakában fontosabb a szerepe a menedzsment összetételének, mint később, miután a vállalat megerôsödött. Ezt alátámasztják a kapott adatok is.

$\mathrm{Az}$ árbevétel mértékét befolyásolja a munkaerô megoszlása is. A legtöbb vállalat a megerósödés időszakában jellemző́n többféle munkaerót is alkalmazott, családtagok és külső alkalmazottak is részt vettek a munkában. 23\%-uk 20 és 50 millió forint közötti árbevételt ért el, 50 és 100 millió forint közötti bevételt 
szerzett 20\%, 34\% pedig 100 és 500 millió forintos bevételt termelt. Másodsorban inkább a külső munkaerő alkalmazása volt a jellemző. A különböző munkaerô alkalmazása és az árbevétel alakulásáról elmondható, hogy közöttük közepes erôsségü összefüggés van, a Phi asszociációs együttható alapján.

Ami az árbevétel és a létszám kapcsolatát illeti, elmondható, hogy mindhárom idôszakban összefüggés van a kettő között. Az alapítás idôszakában a legerôsebb az összefüggés $(0,68)$, de ez a késóbbi időszakokban sem csökken jelentôsen - a Pearson-féle korreláció 0,55 és 0,5 . Elmondható az is, hogy a létszám alakulása a korábbi időszakokban szintén befolyásolja a késôbbi árbevételt, itt is legalább közepesen erôs az összefüggés 0,35-0,53 (11. táblázat).

\section{A nettó árbevétel és az összlétszám összefüggése a különbözó idôszakokban} ( $\mathrm{n}=112$ vállalkozás)

\begin{tabular}{|l|l|l|l|}
\hline \multicolumn{4}{|c|}{ Nettó árbevétel } \\
\hline Összlétszám & $\begin{array}{c}\text { 1. } \\
\text { Alapítás- } \\
\text { kor }\end{array}$ & $\begin{array}{c}\mathbf{2 .} \\
\text { Megerósö- } \\
\text { déskor }\end{array}$ & $\begin{array}{c}\mathbf{3 .} \\
\text { EU-csatla- } \\
\text { kozáskor }\end{array}$ \\
\hline 1. Alapításkor & 0,688 & 0,404 & 0,353 \\
\hline 2. Megerósödéskor & 0,532 & 0,551 & 0,531 \\
\hline 3. EU csatlakozáskor & 0,297 & 0,44 & 0,505 \\
\hline
\end{tabular}

\section{Összegzés}

Mindent összevetve, a felmérésben részt vett magyar kis- és középvállalkozásokról a leírt elemzések alapján kialakítható kép lendületet, rugalmasságot és a kihívásokkal szemben pozitív hozzáállást mutat. A vállalkozások készek a változtatásokra, és növekszik azoknak az aránya, amelyek a hazai piaci lehetóségeken túlra tekintenek. A vállalkozói kedv azonban némi hanyatlást mutat, és számos aggodalmuk is van a vállalkozásoknak. A válaszadók körében az anyagi eszközök biztosítása nem tûnik jelentôs problémának, sốt a támogatásokat sem veszik intenzíven igénybe. Az erôs verseny miatt a vállalkozások mind a hazai, mind a külföldi piacokon valószínúleg a piaci rések felkutatásával, szövetségek létrehozásával vagy üzletrészek eladásával próbálnak sikereket elérni.

Világosan látható, hogy a magyar vállalkozók átléptek a hagyományos kiskereskedelmi és az egyszerú szakipari szolgáltatásokon (Peng, 2000; Kornai, 1992; Ernst et al., 1996). Ügyfélbarát és piacorientált stratégiákkal vannak jelen mind a termék, mind a szolgáltatási iparágakban. A külső és belső korlátozások változatlan fennállása, valamint a hazai és külföldi versenytársak általi fenyegetettség állandósulása ellenére a keresleti igények elemzését, figyelemmel kísérését folyamatossá kell tenni. Kutatásunk is azt jelzi, hogy a megkérdezett 112 vállalkozás igyekszik megfelelni a rájuk váró folyamatos kihívásoknak.

\section{Lábjegyzet}

${ }^{1}$ Az empirikus kutatás az OTKA kutatási célprogram támogatásával készült.

\section{Felhasznált irodalom}

Ács, Z. J. - Varga, A.(2005): Entrepreneurship, Agglomeration and Technological Change. Small Business Economics, 24(3), 323-334. old.

Ács, Z.J. - Isberg, S.C. (1991): Innovation, Firm Size and Corporate Finance: An initial inquiry. Economics Letters, 35(3), 323-326. old.

Ács, Z.J. - Audretsch, D.B. (1993): Conclusion, in Small Firms and Entrepreneurship; an East-West Perspective. In: Acs, Z,J. - Audretsch, D.B. (eds.), Cambridge, UK, Cambridge University Press

Bagchi-Sen, S. (1999): The Small- and Medium-Sized Exporter's Problems: An Empirical Analysis of Canadian Manufacturers. Regional Studies, 33(3), 231-245. old.

Balaton K. (2003): A Magyarországon múködő vállalatok stratégiái. Kihívások és lehetôségek az átalakulási időszak végén (2002-ben). Vezetéstudomány, 1., 2-12. old.

Chetty, S.K. (1999): Dimension in internationalisation of manufacturing firms in the apparel industry. European Journal of Marketing, 33(1/2), 121-142. old.

Chikán A. - Czakó E. (2007): Gazdasági versenyképességünk vállalati nézőpontból. Vezetéstudomány. 5., 1-8. old.

Covin, J.G. - Slevin, D.P. (1991): A Conceptual Model of Entrepreneurship as Firm Behavior. Entrepreneurship Theory and Practice 16(3), 7-25. old.

Csapó K. - Csóri B. - Petheó A. (2004): A magyarországi kis- és közepes vállalkozások digitális tevékenysége az európai uniós csatlakozás tavaszán. Vezetéstudomány, különszám, 73-80. old.

Dichtl, E. M. - Koglmayr, G-Mueller, S. (1990): International orientation as a precondition for export success. Journal of International Business Studies, 21(1), 23-40. old.

Dimitratos, P. - Lioukas, S. - Carter, S. (2004): The Relationship between Entrepreneurship and International Performance: The Importance of Domestic Environment. International Business Review, 13(1), 19-41. old.

Ernst, M. - Alexeev, M. - Marer, P. (1996): Transforming the core: Restructuring industries in Russia and Central Europe. Boulder, CO, Westview 
Etemad, H. - Wright, R.W. (2003): Internationalization of SMEs: Toward a new paradigm. Small Business Economics, 20, 1-4. old.

Eurostat (2002): SMEs in Europe competitevness, innovation and the knowledge-driven economy. Eurostat

Francsovics A. (2006): Besonderheiten der Entwicklung des Controllings. Amicus Kiadó, Budapest

Futó P. - Kállay L. (1994): A kis- és középvállalkozások elterjedése és szerkezete. Statisztikai Szemle, 72(10), 722-738. old.

Greiner, L. (1972): Evolution and Revolution as Organizations Grows. Harvard Business Review, July-August, 37-46. old.

Gross, A. - Banting, P. - Meredith, L. - Ford, D. (1993): Business Marketing. Boston, Houghton Mifflin

Hanks, S.H. - Watson, C.J. - Jannsen, E. - Chandler, G.N. (1993): Tightening the life-cycle construct: A taxonomic study of growth stage configurations in high-technology organizations. Entrepreneurship: Theory and Practice, 2, 5-30. old.

Hills, G. etal., (Eds.) (1995): Marketing and Entrepreneurship: Proceedings of the UIC Symposium. Chicago, IL, University of Illinois at Chicago

Hollenstein, H. (2005): Determinants of international activities: Are SMEs different?" Small Business Economics, 24, 431-450. old.

Holzmuller, H. H. - Kasper, H. (1990): The dccision-makcr and export activity: A cross-national comparison of the foreign orientation of Austrian managers. Management International Review, 30, 217-230. old.

Julien, P. - Ramangalahy, C. (2003): Competitive strategy and performance of exporting SMEs: An empirical investigation of the impact of their export information search and competencies. Entrepreneurship Theory and Practice, 27(3), 227-245. old.

Kadocsa Gy. - Francsovics A. (2006): Controlling Management: Success Factor of Competitiveness of SME. SME in ERA of Globalisation, Conference, Banska Bystrica, szept., 21-22. old.

Kalantaridis, C. (2004): Internationalization, Strategic Behavior and The Small Firm: A Comparative Investigation. Journal of Small Business Management, 42(3), 245-262. old.

Kazanjian, R.K. (1988): Relation of dominant problems to stages of growth in technology based new ventures. Academy of Management Journal, 31, 257-280. old.

Kazanjian, R.K. - Drazin, R. (1989): A state-contingent model of design and growth for technology based new ventures. Journal of Busness Venturing, 5., 137-151. old.

Kiss, K. - Poor, J. - Gross, A - Javalgi, R. - Solymossy, E. (2006): Emerging enterprises. $20^{\text {th }}$ Anniversary Meeting, The UIC Symposium on Marketing \& Entrepreneurship University of Illinois at Chicago, Chicago, Illinois, August, 2-4. old.
Kóhegyi K. (2001): Növekvő és zsugorodó vállalkozások. Cégvezetés, 5., 146-153. old.

KSH (2000): Kis- és középvállalkozások a magyar gazdaságban. Helyzetkép és nemzetközi összehasonlítás. Budapest, Központi Statisztikai Hivatal

KSH (2005): A gazdasági versenyképesség területi különbségei Magyarországon. Győr, Központi Statisztikai Hivatal, augusztus 25.

KSH (2005): Gyorstájékoztató. A regisztrált gazdasági szervezetek száma, II. negyedév, Budapest, Központi Statisztikai Hivatal, július 29.

Knight, G. (1997): Cross-cultural reliability and validity of a scale to measure firm entrepreneurial orientation. Journal of Business Venturing, 12, 213-225. old.

Kornai, J. (1992): The socialist system: The political economy of communism. Princeton, NJ, Princeton University Press

Landstrom, H. (1998): Informal Investors as Entrepreneurs. Technovation 18(5), 321-333. old.

Lyon, D.W. - Lumpkin, G.T. - Dess, G. G. (2000): Enhancing entrepreneurial orientation research: Operationalizing and measuring a key strategic decision making process. Journal of Management, 26(5), 1055-1085. old.

Lumpkin, G.T. - Gregory G. Dess. (1996): Clarifying the Entrepreneurial Orientation Construct and Linking it to Performance. Academy of Management Review, 21(1), 135-172. old.

McDougall, P.P. - Oviatt, B.M. (2000): International entrepreneurship: The intersection of two research paths. Academy of Management Journal, 43(5), 902906. old.

Miller, D. (1983): The correlation of entrepreneurship in three types of firms. Management Science, 29(7), 770 791. old.

Moen, $O$ (2002): The born globals: A new generation of small European exporters. International Marketing Review, 19(2), 156-175. old.

Morris, M.H.-Sexton, D. (1996): TheConcept of Entrepreneurial Intensity: Implications for Company Performance. Journal of Business Research, 36(1), 5-13. old.

Morris, Michael H. (1998): Entrepreneurial Intensity: Sustainable Advantages for Individuals, Organizations, and Societies. Westport, Connecticut, Quorum Books

Naman, J.L., - Slevin, D.P. (1993): Entrepreneurship and the concept of fit: A model and empirical tests. Strategic Management Journal, 14(2), 137-153. old.

Nummela, N. - Saarenketo, S. - Puumalainen, K. (2004): A Global Mindset - A prerequisite for successful internationalization? Canadian Journal of Administrative Sciences, 21(1), 51-64. old.

Nyers J.-Szabó L. (2003): A kis- és középvállalkozások gazdasági jellemzói, kilátásai. Statisztikai Szemle, 81(9), 775-798. old.

OECD/LEED (2005): Business Clusters: Promoting in Central and Eastern Europe. Paris, OECD 
OECD (2002): OECD Small and Medium Enterprise Outlook. Paris, OECD

Oviatt, B.M. - McDougall, P.P. (1994): Toward a theory of international new ventures. Journal of International Business Studies, 25(1), 45-64. old.

Peng, M.W. (2000): Business Strategies in Transition Economies. Thousand Oaks, California, Sage Publications

Phillips, B.D. - Kirchoff, B.A. (1989): Innovation and Growth Among New Firms in the U.S. Economy. Babson Park, MA, Babson Entrepreneurial Research Conference

Poór J. (2005): Nemzetköziesedés és globalizáció az emberieróforrás-menedzsmentben. In. Harvard Business Manager, December, 68-78. old.

Poór J. (2006): HR mozgásban - nemzetköziesedés az emberieróforrás-menedzsmentben. Budapest, MMPC Kiadó

Reid, S.D. (1984): Information acquisition and export entry decisions in small firms. Journal of Business Research, 12(2), 141-157. old.

Román Z. (1992): Vállalkozói sikereket - erôs kisvállalatokat. Budapest, Magyar Kisvállalati Társaság

Román Z. (1977): Vállalkozás- és kisvállalat-kutatások. Vezetéstudomány, 12. sz., 47-53. old.

Román Z. (1995): Beszállítások a feldolgozóiparban. Közgazdasági Szemle, 12. sz., 1165-1176. old.

Román Z. (2002): Vállalkozáserôsítô és/vagy kisvállalat-politika? A vállalkozás- és kisvállalat-kutatásokról. Vezetéstudomány, 8-9. sz., 18-26. old.

Rowden, R.W. (2001): Research note: How a small business enters the international market. Thunderbird International Business Review. 43(2), 257-268. old.

Rutherford, M.W. - Buller, P.F. - McMullen, P.R. (2003): Human Resource Management Problems over the Life-Cycle of Small to Medium-Sized Firms. Human Resource Management, 4, 321-335. old.

Salamonné Huszty A. (2006): Magyarországi kis- és középvállalkozások életútjának modellezése. Competitio V. évf. 1.

Sarasvathy, S. (2004): The questions we ask and the questions we care about: Reformulating some problems in entrepreneurship research. Journal of Business Venturing. 19(5), 707-720. old.

Sengenberger, W. - Loveman, G.W. - Piore, M.J. (1990): The Re-emergence of Small Enterprises: Industrial Restructuring in Industrialied Countries, ILO, Geneva

Schumpeter, J. (1934): The Theory of Economic Deevelopment An Inquiry into Profits, Capital, Credit, Interest, and the Business Cycle. Cambridge Mass., Harvard University Press
Schumpeter, J. (1939): Busness Cycle: A Theoretical, Historical and Statistical Analysis of the Capitalist Process. New York, McGraw-Hill

Storey, D.J. - Westhead, P. (1996): Management training in small firms - a case of market failure. Human Resource Management Journal, 7(2), 61-71. old.

Storey, D.J. (1994): Understanding the Small Business Sector. London, Routledge

Szerb L. (2006): Vállalkozói aktivitás alakulása Magyarországon a 2000-es években. (előadás) 44. Közgazdász vándorgyúlés „Magyar helyteremtés Európában”, Magyar Közgazdasági Társaság, Nyíregyháza, augusztus 31-szeptember 2.

Szerb L. (2000): Kisvállalati gazdaságtan és vállalkozástan. Pécsi Egyetem, Pécs

Szerb L. (2004): A vállalkozásindítás adminisztrációs költségei az Amerikai Egyesült Államokban (Washington állam) és Magyarországon. Vezetéstudomány, 11. sz., 42 -54 . old.

Tesar, G.-Moini, A.H. (1998): Longitudinal study of exporters and nonexproters: A focus on smaller manufacturing enterprises. International Business Review, 7, 291-313. old.

Todd, P.R. (2006): An Empirical Investigation of Entrepreneurial Orientation, Internationalization, and Performance of Small and Medium-Sized Enterprises (SMEs). Unpublished DBA dissertation. Cleveland, Cleveland State University

Ullmann, A.A. - Lewis, A. (1993): Privatization and Entrepreneurship: The Managerial Challenge in Central and Eastern Europe. New York, IBP/Haworth Press

Underwood, T. (2003): Export assistance for small and medium sized enterprises offered by the International Trade Administration, U.S. Department of Commerce, U.S. DOC/ITA/TD/OEABO/Small and Minority Exporters Division

Wiklund, J - Shepherd, D. (2003): Knowledge-Based Resources, Entrepreneurial Orientation, and the Performance of Small and Medium-Sized Businesses. Strategic Management Journal, 24(13), 1307-1314. old.

Zahra, S.A. - Jennings, D.F. - Kuratko, D.F. (1999): The Antecedents and Consequences of FirmLevel Entrepreneurship: The State of the Field." Entrepreneurship Theory and Practice, 24(2), 45-65. old.

Cikk beérkezett: 2007. 2. hó

Lektori vélemény alapján átdolgozva: 2007. 7. hó 